\title{
Van Kahvaltı Salonları Hakkındaki Müşteri E-Şikâyetlerinin Değerlendirilmesine Yönelik Bir Araştırma
}

\section{A Research on the Evaluation of Customer E-Complaints about Van Breakfast Lounges}

\author{
Dr. Öğr. Üyesi Hasan KÖŞKER \\ Zonguldak Bülent Ecevit Üniversitesi \\ Karadeniz Ereğli Turizm Fakültesi, \\ Zonguldak, Türkiye \\ E-posta: hasankosker@beun.edu.tr
}

Öz

Bu araştırmada, Türkiye'nin değişik illerinde faaliyet gösteren Van kahvaltı salonlarına yönelik müşteri şikâyetlerinin belirlenmesi ve şikâyetlere yönelik işletmelere çözüm önerilerinin geliştirilmesi amaçlanmaktadır. Araştırma verileri nitel araştırma yöntemi kapsamında doküman inceleme tekniği kullanılarak 1 Ocak 2013-20 Nisan 2020 tarihleri arasında tripadvisor.com internet sitesinde 22 Van kahvaltı salonu hakkında yapılmış müşteri yorumlarından elde edilmiştir. Araştırmada memnuniyet içeren ve ortalama kategorideki müşteri yorumlarına genel anlamda değinilmiştir. Ancak şikâyet içeren 2 puan ve altındaki 162 müşteri yorumu içerik analizi tekniği ile analiz edilerek yorumlanmıştır. Bulgular; şikâyetlerin yiyecek ve içecek, hizmet kalitesi, fiyat, fiziki koşullar ve diğerleri olmak üzere 5 ana tema ve 24 alt temadan kaynaklandığını ortaya koymaktadır. Kahvaltı salonu işletmecilerinin tespit edilen müşteri şikâyetlerini dikkate alarak gerekli iyileştirmeleri yapmaları müşteri memnuniyetini artıracaktır.

Anahtar Kelimeler: Van kahvaltı salonları, Müşteri, E-şikâyet, TripAdvisor.

\section{Abstract}

In this research, it is purposed to determine customer complaints and to develop solutions to the Van Breakfast lounges operating in different provinces in Turkey. The research data were obtained from customer comments about 22 Van breakfast lounges on tripadvisor.com website between January 1, 2013 and April 20, 2020 using the document review technique within the scope of qualitative research method. In the research, customer comments containing satisfaction and also in the average category were mentioned in general. However, 162 customer comments containing complaints of 2 points or less were analyzed and interpreted using content analysis technique. Results; It reveals that the complaints stem from 5 main themes and 24 sub-themes: food and beverage, service quality, price, physical conditions and others. Customer satisfaction will increase if the breakfast lounges operators make the necessary improvements by taking into account the customer complaints detected.

Key Words: Van breakfast lounges, Customer, E-complaint, TripAdvisor. 


\section{Extended Summary}

\section{Purpose}

The original Van breakfast consists of natural and local foods. In this research, identification of customer complaints about Van breakfast lounges operating in different provinces in Turkey and has been intended to develop solutions for those businesses. Knowing customer complaints about Van breakfast lounges will provide important information to those who operate these rooms. Knowing which issues customers complain about, can help businesses develop appropriate solutions. Thus, it can be possible to increase customer satisfaction and decrease customer complaints. When the literature is analyzed, it is seen that there are studies dealing with complaints about restaurants selling national, regional or local products. However, no research has been found that deals with complaints about breakfast lounges. It can be said that the research addressed in this aspect is important and can contribute to the related literature.

\section{Background}

Complaint is a term that expresses the inability to meet expectations (Barlow \& Moller, 2008: 22). Consumer complaints may be caused by defective or low quality products or services that are not satisfactory (Chan et al., 2006: 48), cannot meet consumer expectations unkind behavior during the purchase and sale of the service, inappropriateness of the service environment, delays, and lack of desired product or service (Askun, 2008: 223). Although consumer complaints are perceived as negative by some businesses, they should actually be considered as an important feedback. Because understanding the importance of the causes and consequences of consumer complaints and acting accordingly provide an advantage to businesses in a competitive environment (Ibiş et al., 2019: 506), give them a second chance to correct their mistakes, increase their service quality (Bell et al., 2004), turn customer dissatisfaction into satisfaction, and customer disbelief into confidence (Kim \& Chen, 2010). For this reason, businesses should not be disturbed by complaints from their customers and should be satisfied (Ro, 2013).

\section{Method}

The universe of the research is Van breakfast lounges. The sample of the study is composed of 22 Van breakfast lounge businesses commented on the tripadvisor.com website. Research data was obtained from customer comments about Van breakfast lounges. 721 in Turkish and 396 in English and total of 1.117 comments were taken into consideration. The website requires its customers to evaluate about the business from which they receive services with the categories $5=$ Excellent, $4=$ Very Good, $3=$ Average, 2 = Bad, 1 = Terrible. In this research, customer reviews that contain satisfaction and are in the average category are generally mentioned. However, 162 customer reviews containing complaints (in the category $2=$ bad and $1=$ terrible) were analyzed in detail by content analysis technique, which is the qualitative research method.

\section{Findings}

$72.86 \%$ (814) of the comments made on Van breakfast lounges consist of satisfaction, $12.62 \%(141)$ is at the average level without complaints and $14.49 \%$ (162) of the complaints. Considering these rates, it can be said that customers are generally 
satisfied with Van breakfast. On the other hand, it is not true to ignore the customers complaining. TripAdvisor users made 162 comments with complaints. A total of 410 complaints were identified from these comments. These complaints are classified and grouped according to their subjects. Grouping consists of 5 main themes and 24 subthemes. The most common complaints were about food and beverage 150 (37\%), service quality $27 \%(113)$ and price $21 \%(88)$. These are followed by complaints on physical conditions $9 \%(36)$ and other $6 \%(23)$ issues.

\section{Results}

Although the area of research is different from the researches carried out so far, most of the main themes of the detected complaints are similar to other research results. Some of the sub-themes identified as the subject of complaints in the study differ from other studies. These differences are; the amount of portions is low, the food left over from other tables is served to other tables, additional charge from food and drink ordered second time, the amount of portion size is not taken into account and per person charge and the place is very crowded.

Based on the findings obtained from the research, some suggestions can be made to the operators of the Van breakfast lounge. From the comments of customers coming to Van breakfast lounges, it is seen that most of the customers have read the comments about Van breakfast lounges beforehand, they go to these breakfast rooms with the expectation of quality, naturalness, locality, originality, freshness and diversity and when we say Van breakfast they expect an excellent menu that satisfies the eyes and abdomen. At this point, the issue that businesses should pay attention to take care of using local and natural foods of Van region without reducing the amount of portions, to stay away from super market products and ready-made foods, and to apply a reasonable price policy without not to compromise on originality, quality, variety and taste.

The last suggestion that can be made to the breakfast lounge operators is "Customers are our bread and butter" and every customer is precious. Based on this understanding, customer complaints containing complaints should not be disturbed, complaints should be taken into account, analyzed, problems should be identified and solution oriented policies should be displayed.

\section{Giriş}

Her ülkenin ve bölgenin kendine özgü mutfak kültürü, yöresel yemekleri ve kahvaltı alışkanlıkları vardır. Van uzun yıllara dayanan çok kültürlü tarihi geçmişiyle kendine özgü zengin bir mutfak kültürüne sahiptir. Van'ın mutfak kültüründen bahsedildiğinde kuşkusuz akla gelen en önemli unsurdan biri Van kahvaltısıdır (Nakiboğlu, 2017). Van kahvaltısı bol çeşitliliği, sağlıklı ve besleyici özelliğiyle Van iliyle özdeşleşmiş bir marka değeridir. Orijinal Van kahvaltısı; Van balı, yoğurt kaymağı, süt kaymağı, yayık tereyağı, cacık, otlu peynir, örme peynir, beyaz peynir, kavurmalı-sucuklu yumurta, zeytin, murtuğa, kavut, gencirütten gibi doğal ve yerel yiyeceklerden oluşmaktadır (Kılıçhan ve Köşker, 2015: 104). Van kahvaltı salonları yıllarca sadece Van ilinde hizmet etmekteydiler. 2011 yılında Van'da meydana gelen depremden sonra ticari faaliyetler belirli bir süre durmak zorunda kaldı. Bu süreçte bazı işletmeciler, büyük ve turistik bazı kentlerde Van kahvaltı salonu açmaya başladılar. Böylece yöresel bir marka olan Van kahvaltısı daha geniş tüketici kitlesine ulaşmış oldu. Van kahvaltı salonlarının Türkiye'nin değişik illerinde açılması ve sayı olarak artması orijinallik, doğallık, kalite, tazelik, lezzet, çeşitlilik gibi sorunları beraberinde getirmiştir. 
Turizm sektöründe hizmet verimliliği ve kalitesinin ilk yasası işleri doğru yaparak müşteri memnuniyetini sağlamaktır (Chan ve diğ., 2016: 46). Ancak turizm ürünlerinin özelliklerinden dolayı müşteri şikâyetleri hemen hemen kaçınılmazdır. Turizm ürünü, genellikle hizmet olarak sunulmakta ve hizmette tam anlamda standartlaşma mümkün olamamaktadır. Ürünün hazırlığı ve sunumu, çalışandan çalışana değiştiği gibi, hizmeti satın alan tüketicilerde oluşturulduğu tatmin de, kişiden kişiye değişmektedir. Turizm ürünleri eş zamanlı olarak hazırlanıp, sunulduğundan, tüketici şikâyetlerine ortam hazırlamaktadır (Kozak, 2007: 140). Kaliteli turizm işletmelerinde bile ara sıra bazı hizmet hatalarından kaynaklanan şikâyetler olabilmektedir. Hizmet hatalarının telafisi ancak müşterilerin geri bildirimleri ile mümkündür (Gursoy ve diğ., 2003: 26).

Günümüzde sosyal medya platformları müşterilerin deneyimlemiş oldukları ürün, hizmet veya işletmeler hakkında memnuniyet veya e-şikâyet içeren yorumlar yazmalarına ve işletmelerin de bu şikâyetlere cevap verebilmesine olanak sağlamaktadır. Turistik mal ve hizmetlerden yararlanmak isteyen birçok potansiyel tüketici, turizm işletmeleriyle ilgili dijital platformlardaki yorumlarını okuyarak müşteri deneyimlerini öğrenmeye çalışmaktadır (Alabay, 2012). Önemli bilgi kaynağı olan dijital platformlardaki yorum ve değerlendirmeler, tüketiciler tarafından reklam ve değişik pazarlama araçlarından gelen mesajlardan daha gerçekçi ve işletmelerin sunduğu bilgilerden daha güvenilir olarak algılanmaktadır (Çuhadar ve Güney, 2018). Turizm işletmelerine yönelik olumlu veya şikâyet içerikli yorumlar ve işletmelerin şikâyetlere yönelik çözüm önerileri potansiyel müşterilerin karar ve tercihlerini etkilemektedir (Defranco ve diğ., 2005; Genç ve Batman, 2018). Bu nedenle işletmelerin dijital platformdaki şikâyetleri önemsemeleri, şikâyeti yazan müşteriyle iletişime geçmeleri, şikâyeti çözmeleri veya şikâyet edilen konudan dolayı makul bir gerekçe ile özür dilemeleri gerekmektedir (Alabay, 2012; Aylan ve diğ., 2016). Şikayetler her zaman olabilir, önemli olan şikayete neden olan hataları telafi edip müşteri sadakatini sağlayabilmektir (Gursoy ve diğ., 2003). İşletmelerin temel varlık nedeni kendilerine ürün veya hizmet sundukları müşterilerdir. İşletmeler, müşterilerini memnun edebildikleri sürece ayakta kalabileceklerini unutmaması gerekmektedir (KalDer, 2020).

Bu araştırmada, Türkiye'nin değişik illerinde faaliyet gösteren Van kahvaltı salonlarına yönelik müşteri şikâyetlerinin belirlenmesi ve şikâyetlere yönelik işletmelere çözüm önerilerinin geliştirilmesi amaçlanmaktadır. Araştırma kapsamında kavramsal çerçeve ele alınmış, ardından araştırmanın yöntemi açıklanarak veriler analiz edilmiştir. Sonra tespit edilen şikâyet konuları genel çerçeveden ele alınarak yorumlanmıştır. Sonuç bölümünde tespit edilen şikayetlerden yola çıkılarak literatür ışığında karşılaştırmalar yapılmış ve geleceğe yönelik bazı öneriler getirilmiştir.

\section{Literatür Taraması}

Şikâyet, beklentilerin karşılanamamasını ifade eden bir terimdir (Barlow ve Moller, 2008: 22). Konuyla ilgili tanımlara bakıldığında şikâyetin, tüketicilerin ürün veya hizmetlerden memnuniyetsizliğini ifade eden ve çözüm bekleyen bir tatminsizlik durumu şeklinde ifade edildiği görülmektedir. Bell ve diğ., (2004: 116) şikâyeti, işletmelerin ürettiği ürün veya hizmetlerden memnun kalmayan tüketicilerin geri bildirimi olarak, Velazquez ve diğ., (2006: 495) şikayeti, tüketicilerin tatmin edici olmayan bir deneyimle karşılaştıklarında verdikleri bir tepki olarak, Akoğlan Kozak ve Güçlü (2006: 99) şikâyeti, istek, ihtiyaç ve beklentilerin karşılanmaması sonucu ortaya çıkan davranışla, sözle veya yazılı olarak ifade edilen tatminsizlik durumu olarak tanımlamaktadır. ISO (2018) ise şikâyeti, bir kuruluş veya işletmeye ait ürün veya 
hizmetlerden dolayı açık veya üstü kapalı olan bir cevap veya çözüm bekleyen memnuniyetsizliğin ifadesi olarak tanımlamaktadır.

Tüketici şikayetleri, tatmin edici olmayan, tüketici beklentilerini karşılayamayan kusurlu veya düşük kalitedeki ürün veya hizmetlerden (Chan ve diğ., 2016: 48), hizmetin alım ve satımı sırasındaki nezaketsiz davranışlardan, hizmet ortamının uygunsuzluğundan, gecikmelerden, istenilen ürün veya hizmetin olmamasından kaynaklanabilmektedir (Aşkun, 2008: 223). Tüketici şikâyetleri bazı işletmeler tarafından olumsuz olarak algılansa da aslında bu şikâyetler önemli bir geri bildirim olarak değerlendirilmelidir. Zira tüketici şikâyetinin sebep ve sonuçlarının önemini anlamak ve buna göre hareket etmek, rekabet ortamında işletmelere avantaj sağlamakta (İbiş ve diğ.,, 2019: 506), onlara hatalarını düzeltme, hizmet kalitelerini artırma (Bell ve diğ., 2004), müşteri memnuniyetsizliğini memnuniyete, müşteri güvensizliğini güvene dönüştürmek için ikinci bir şans vermektedir (Kim ve Chen, 2010). Bu nedenle işletmeler müşterilerinden gelen şikâyetlerden rahatsız olmamalı, bilakis memnun olmalıdır (Ro, 2013). Çünkü her şikâyet tüketici ile işletme arasındaki sorunlu ilişkiyi düzeltme fırsatı vermektedir. Şikâyetler olmazsa bazı küçük sorunlar, aksilikler, performans düşüklükleri büyük sorunlar ortaya çıkmadan bulunamaz ve çözülemez (Kozak, 2007).

İyi müşteri yönetim sistemlerine sahip olan işletmeler, aynı zamanda iyi yönetilebilir müşteri şikâyet sistemine sahiptirler. İyi bir şikâyet sistemi, müşterilerin şikâyetlerini istedikleri zaman hızı bir şekilde iletmelerine olanak sağlamaktadır. Böylece işletmelerin hızlı ve kesin bir şekilde çözüm sunmaları (Yaacob, 2010: 3175) ve müşteri memnuniyeti sağlamaları mümkün olabilmektedir (Gursoy ve diğ., 2003). İşletmelerde iyi bir şikayet sistemi olmadığı durumlarda, müşteriler şikayet yerine ürün veya hizmet tedarikçilerini değiştirmekte, yaşadıkları kötü tecrübeleri aileleri ve arkadaşlarıyla paylaşarak onları uyarmayı ve onların da benzer bir surunla karşılaşmamalarını tercih etmektedirler (Phau ve Sari, 2004).

Konu ile ilgili literatür incelendiğinde ulusal ve uluslararası ölçekte yiyecek içecek sektöründe müşteri şikayetlerini konu alan birçok araştırmaya rastlanmaktadır. Bu araştırmaların ulusal yemek sunan, hızlı yiyecek servisi yapan, masa servisi yapan, otantik veya yöresel ürün sunan restoranlar üzerine yoğunlaştığı görülmektedir. Restoranlara yönelik şikayetlerin genellikle yiyecek içecek (yiyeceğin özgünlüğü, tazeliği, gıda hijyeni, porsiyon miktarı), hizmet kalitesi (kibarlık, nezaket, vasıfsızlık, doğru servis, hızlı servis), fiyat (pahalıık, ek ücret alınması, hesabın şişirilmesi), fiziki koşullardan (ambiyans, dekorasyon, havalandırma, ışık, hijyen, müzik) kaynaklandığı görülmektedir (Su ve Bowen, 2000; Defranco ve diğ., 2005; Liu ve Jang, 2009; Chan ve diğ., 2016; Erdem ve Yay, 2017; Taştan ve Kızılcık, 2017; Şahin ve diğ., 2018; İbiş ve diğ., 2019; Yaşar, 2019).

Su ve Bowen (2000) Amerika'da masa servisi yapan restoranlar üzerine yaptıkları araştırmada, tüketici şikâyetlerinin yavaş ve yetersiz servis, hatalı pişirme yöntemleri, işletmelerin fiyat politikası ve hatalı servis yöntemlerinden kaynaklandığını tespit etmişlerdir. Defranco ve diğ., (2005) Hong Kong'un Sar ve Amerika'nın Houston kentlerindeki otel restoranları üzerine yaptıkları araştırmada, iki ülke arasındaki kültürel nedenlerden dolayı şikâyet konularının önem sırasının değiştiği ifade edilmektedir. Buna karşın restoranların fiziksel temizliği, servisin kalitesi, personelin hizmet anlayışı ile yiyecek ve içeceğin lezzeti konusunda şikâyetlerin olabilme olasılığının oldukça yüksek olduğu vurgulanmaktadır. 
Liu ve Jang (2009) Amerikalı müşterilerin Amerika'daki Çin restoranlarına yönelik algıları üzerine yaptıkları araştırmada, müşterilerin önem verdiği unsurların lezzet, gıda güvenilirliği, tazelik, servis personelinin niteliği, restoranın atmosferi olduğu belirtilmektedir. Diğer taraftan restoranlardaki müzik, aydınlatma, mekân tasarımı, dekorasyonun müşteriler tarafından yeterince beğenilmediği ve bu konularda şikâyetlerin olduğu tespit edilmiştir. Chan ve diğ., (2016) Hong Kong'ta tam donanımlı servis yapan restoranlar üzerine yaptıkları araştırmada, tüketici şikayetlerinin önem sırası personelin tutumları, yüksek fiyat, personel eksikliği, fazla hesap yazmak, söz verilen kapsayıcı hizmetler, gıda kalitesi ve hijyen konusu şeklinde sıralanmaktadır.

Dalgıç ve diğ., (2016) Mersin ve Hatay'da faaliyet gösteren restoran işletmeleri üzerine yaptıkları araştırmada, tüketici şikâyetlerinin gıda, servis, atmosfer ve diğer özelliklerden (adil fiyat, gıda özgünlüğü ve çevresel özgünlük) kaynaklandığı belirtilmektedir. Giritlioğlu ve diğ., (2016) Antalya'da Osmanlı ve Türk mutfağı üzerine faaliyet gösteren yiyecek ve içecek işletmeleri üzerine yaptıkları araştırmada, tüketici şikayetlerinin lezzet, hizmet kalitesi, yüksek fiyat, kalite tutarsızlığı, personel davranışları, ortamın uygunsuzluğu, hijyen, göstermelik yapılan yorumlar, çalışanların etik olmayan davranışları, menüdeki çeşitlilik, yemek ve fiyat uyumu, işgören profesyonelliği, yönetici davranışı, siparişlerin karşılanması, menünün anlaşıırlığı, işletmeyle iletişim ve ulaşım konularından kaynaklandığı sonucuna ulaşılmıştır.

Erdem ve Yay (2017) Antalya il merkezindeki birinci sınıf restoranlar üzerine yaptıkları araştırmada, tüketici şikâyetlerinin sırasıyla fiyat, hizmet ortamı, menü, personel, servis, yiyecek ve içeceklerden kaynaklandığı tespit edilmiştir. Taştan ve Kızılcık (2017) Kahramanmaraş'ta faaliyet gösteren yiyecek içecek işletmeleri üzerine yaptıkları araştırmada, tüketici şikâyetlerinin yiyecek-içecek, personel, fiyat, fiziki yapı, servis, atmosfer, menü ve temizlik konularından kaynaklandığı tespit edilmiştir. Unur ve diğ., (2017) Adana'da yerel lezzet sunan restoran işletmeleri üzerine yaptıkları araştırmada, tüketici şikayetlerinin yiyecek-içecek, servis, ambiyans ve diğer nedenlerden (fiyat, personelin tutum ve davranışları, gıda özgünlüğü, otopark, standart kalitede lezzet) kaynaklandığı vurgulanmaktadır.

Şahin ve diğ., (2018) Alaçatı'da deniz mahsulleri sunumu yapan restoranlar üzerine yaptıkları araştırmada, tüketici şikayetlerinin sırasıyla fiyat, ürün, tutundurma, dağıtım, müşteri ve yasal boşluklardan kaynaklandığı tespit edilmiştir. İbiş ve diğ., (2019) İstanbul'daki Çin restoranları üzerine yaptıkları araştırmada, tüketici şikâyetlerinin ürün, fiyat, fiziki koşullar ve hizmet kalitesi olmak üzere 4 ana tema ve 12 alt temadan kaynaklandığı tespit edilmiştir. Yaşar (2019) Kastamonu'da yöresel yiyecek ve içecek hizmeti sunan işletmeler üzerine yaptığı araştırmada, tüketici şikâyetlerinin sırasıyla yiyecek-içecek, hizmet ortamı, fiyat, personel, servis ve menüyle ilgili özelliklerden kaynaklandığı tespit edilmiştir.

\section{Yöntem}

Bu araştırmada, Türkiye'nin değişik illerinde faaliyet gösteren Van kahvaltı salonlarına yönelik müşteri şikâyetlerinin belirlenmesi ve şikâyetlere yönelik işletmelere çözüm önerilerinin geliştirilmesi amaçlanmaktadır. Van kahvaltı salonlarında müşteri şikâyetlerinin hangi konulardan kaynaklandığının bilinmesi işletmelere müşteri memnuniyeti ve sadakati açısından önemli bilgiler sağlayacaktır. Böylece müşteri memnuniyetinin artması ve müşteri şikâyetlerinin azalması mümkün olabilecektir. Literatür incelendiğinde ulusal, bölgesel veya yöresel ürün satan restoranlara yönelik şikâyetlerin ele alındığı araştırmaların olduğu görülmektedir. Ancak kahvaltı salonu işletmelerine yönelik şikâyetlerin ele alındığı bir araştırmaya rastlanamamıştır. Bu 
yönüyle ele alınan araştırmanın önemli olduğu ve literatüre katkıda bulunabileceği düşünülmektedir.

Araştırmanın evrenini Türkiye genelindeki Van kahvaltı salonları, araştırmanın örneklemini ise tripadvisor.com internet sitesinde hakkında yorum yapılmış 22 Van kahvaltı salonu işletmesi oluşturmaktadır. Bu kahvaltı salonları; Van (5), İstanbul (6), Konya (2), Adana (1), Aksaray (1), Alanya (1), Antalya (1), Bursa (1), Elazığ (1), Kayseri (1), Nevşehir (1) ve Şanlıurfa'da (1) faaliyet göstermektedirler. Örneklem olarak tripadvisor.com internet sitesinde yer alan Van kahvaltı salonu işletmelerinin tercih edilmesinin başlıca nedeni ise bu sitesinin dünyada en çok kullanılan ve tercih edilen çevrimiçi konaklama, restoran ve seyahat bilgi kanalı olması ve 700 milyondan fazla müşteri yorumunu içermesinden kaynaklanmaktadır (TripAdvisor, 2020).

Araştırma verileri nitel araştırma yöntemi kapsamında doküman inceleme tekniği kullanılarak 1 Ocak 2013-20 Nisan 2020 tarihleri arasında Van kahvaltı salonları hakkında yapılmış müşteri yorumlarından elde edilmiştir. Türkçe 721, İngilizce 396 olmak üzere toplam 1.117 yorum değerlendirilmeye alınmıştır. Belirli zaman diliminin dikkate alınması ile sadece Türkçe ve İngilizce dillerinde yapılan yorumların değerlendirmeye alınması araştırmanın başlıca sınırlılıklarını oluşturmaktadır. İnternet sitesi, müşterilerinden hizmet aldıkları işletme hakkında 5= Mükemmel, 4= Çok İyi, 3= Ortalama, 2= Kötü, 1= Berbat kategorileri ile değerlendirme yapmasını istemektedir. Bu araştırmada memnuniyet içeren ve ortalama kategorideki müşteri yorumlarına genel olarak değinilmiştir. Şikâyet içeren (2= Kötü ve 1= Berbat kategorisinde yer alan) 162 müşteri yorumundaki 410 şikâyet konusu ana ve alt temalara göre gruplandırılarak nitel araştırma yöntemi kapsamında içerik analizi tekniği ile analiz edilerek yorumlanmıştır. İçerik analizi, bilgi değeri taşıyan her türlü verinin araştırma amacı doğrultusunda taranması, sınıflandırılması, özetlenmesi, çözümlenmesi, yorumlanması işlemlerini kapsayan bilimsel bir araştırma yöntemidir (Yurtseven ve diğ., 2013: 73). Böylece toplanan verileri açıklayabilecek kavramlara, ilişkilere ulaşılmaya çalışılmakta, verilerde gizli olabilecek gerçekler ortaya çıkarılmaya çalışılmaktadır (Yıldırım ve Şimşek, 2011: 39).

\section{Bulgular}

\subsection{Van Kahvaltı Salonlarıyla İlgili Genel Değerlendirmelere Yönelik Bulgular}

Tablo 1'de Türkiye'nin farklı illerinde faaliyet gösteren Van kahvaltı salonlarına yönelik 721'i Türkçe, 396'sı İngilizce olmak üzere toplam 1.117 müşteri yorumu yer almaktadır. Tabloda gizlilik ve bilimsel etik nedeniyle işletme isimlerine ve bulundukları illere yer verilmemiştir. Türkçe yorumların \%63,38'i (457) memnuniyet içerikli, \%18,08'i (116) şikâyet içermeyen genel anlamda ortalama düzeyde, \%20,51'i (148) ise şikâyet içeren yorumlardan oluşmaktadır. İngilizce yorumların \%90,14'ü (357) memnuniyet içerikli, $\% 6,31$ 'i (25) şikâyet içermeyen genel anlamda ortalama düzeyde, \%3,5'i (14) ise şikâyet içeren yorumlardan oluşmaktadır. Bulgular yerli müşterilerin yabancı müşterilerden daha çok şikâyetçi oldukları ortaya koymaktadır. Bu durum yerli müşterilerin Van kahvaltı salonlarına daha yüksek bir beklenti içinde gitmelerinden kaynaklanabilir. Toplam yorumlara bakıldığında, yorumların \%72,86'sı (814) memnuniyet içerikli, \%12,62'si (141) şikâyet içermeyen genel anlamda ortalama düzeyde, \%14,49'u (162) ise şikâyet içeren yorumlardan oluşmaktadır. Bulgular göz önüne alındığında müşterilerin genel anlamda Van kahvaltısından memnun oldukları söylenebilir. Ancak şikâyetçi olan müşterileri görmemezlikten gelmek doğru değildir. Müşteri şikâyetlerinin dikkate alınması, şikâyet konularına uygun çözümlerin üretilmesi müşteri memnuniyetini artıracaktır. 
Tablo 1: İşletmelere Göre Van Kahvaltısı Hakkındaki Yorumların Kategorik Dağılımı

\begin{tabular}{|c|c|c|c|c|c|c|c|c|c|c|}
\hline İşletme No & \multicolumn{2}{|c|}{ Mükemmel } & \multicolumn{2}{|c|}{ Çok İyi } & \multicolumn{2}{|c|}{ Ortalama } & \multicolumn{2}{|c|}{ Kötü } & \multicolumn{2}{|c|}{ Berbat } \\
\hline & Türkçe & İngilizce & Türkçe & İngilizce & Türkçe & İngilizce & Türkçe & İngilizce & Türkçe & İngilizce \\
\hline 1 & 3 & - & - & 3 & 7 & - & - & - & 7 & - \\
\hline 2 & 22 & 8 & 10 & 3 & 20 & 1 & 5 & - & 14 & - \\
\hline 3 & 12 & 1 & 17 & 1 & 10 & - & 6 & - & 16 & - \\
\hline 4 & 52 & 4 & 28 & 1 & 22 & 2 & 6 & 1 & 15 & - \\
\hline 5 & 2 & - & - & - & - & - & 1 & - & 3 & - \\
\hline 6 & 20 & 20 & 4 & 3 & 3 & - & 1 & - & 3 & 1 \\
\hline 7 & 4 & 1 & - & - & 1 & - & - & - & - & - \\
\hline 8 & 100 & 237 & 34 & 61 & 14 & 19 & 2 & 2 & 10 & 9 \\
\hline 9 & 2 & - & - & - & - & - & - & - & - & - \\
\hline 10 & 2 & 3 & 4 & 1 & 4 & - & 2 & - & - & - \\
\hline 11 & 6 & 1 & 2 & 1 & 13 & 3 & 11 & - & 6 & 1 \\
\hline 12 & 3 & - & - & - & 2 & - & 2 & - & - & - \\
\hline 13 & 2 & - & 5 & - & 3 & - & 4 & - & 1 & - \\
\hline 14 & 4 & - & 1 & - & 1 & - & 1 & - & - & - \\
\hline 15 & 15 & - & 3 & - & 2 & - & - & - & 7 & - \\
\hline 16 & 11 & 4 & 1 & - & - & - & 1 & - & - & - \\
\hline 17 & 6 & 2 & 4 & - & 4 & - & 1 & - & 7 & - \\
\hline 18 & 1 & - & 3 & - & - & - & - & - & - & - \\
\hline 19 & - & - & - & - & 3 & - & 1 & - & - & - \\
\hline 20 & - & - & 1 & - & - & - & - & - & 4 & - \\
\hline 21 & 60 & 2 & 8 & - & 7 & - & 3 & - & 8 & - \\
\hline 22 & 2 & - & 3 & - & - & - & - & - & - & - \\
\hline Toplam & 329 & 283 & 128 & 74 & 116 & 25 & 47 & 3 & 101 & 11 \\
\hline$\%$ & 45,63 & 71,46 & 17,75 & 18,68 & 18,08 & 6,31 & 6,51 & 0,75 & 14 & 2,75 \\
\hline \begin{tabular}{|l|} 
Genel Topl. \\
\end{tabular} & \multicolumn{2}{|c|}{612} & \multicolumn{2}{|c|}{202} & \multicolumn{2}{|c|}{141} & \multicolumn{2}{|c|}{50} & \multicolumn{2}{|c|}{112} \\
\hline Genel \% & \multicolumn{2}{|c|}{54,78} & \multicolumn{2}{|c|}{18,08} & \multicolumn{2}{|c|}{12,62} & \multicolumn{2}{|c|}{4,47} & \multicolumn{2}{|c|}{10,02} \\
\hline
\end{tabular}

\subsection{Van Kahvaltı Salonlarında Şikâyet Edilen Konulara Yönelik Bulgular}

TripAdvisor kullanıcıları şikâyet içerikli 162 yorumunda bulunmuştur. Bu yorumlardan toplam 410 şikâyet tespit edilmiştir. Şikâyetler konularına göre tasnif edilerek gruplandırılmıştır. Gruplandırma 5 ana tema ve 24 alt temadan oluşmaktadır. Ana temalar; yiyecek içecek, hizmet kalitesi, fiyat, fiziki koşullar ve diğerleri şeklinde gruplandırılmıştır. Şekil 1'de şikâyetlerin ana temalarına göre frekans ve yüzdelik oranları görülmektedir. En fazla şikâyet yiyecek ve içecek \%37 (150), hizmet kalitesi $\% 27$ (113) ve fiyat \%21 (88) konusunda yapılmıştır. Bunları fiziki koşullar \%9 (36) ve diğer \%6 (23) konularda yapılan şikâyetler takip etmektedir. 


\section{Şekil 1: Şikâyetlerin Konularına Göre Frekans ve Yüzdelik Oranları}

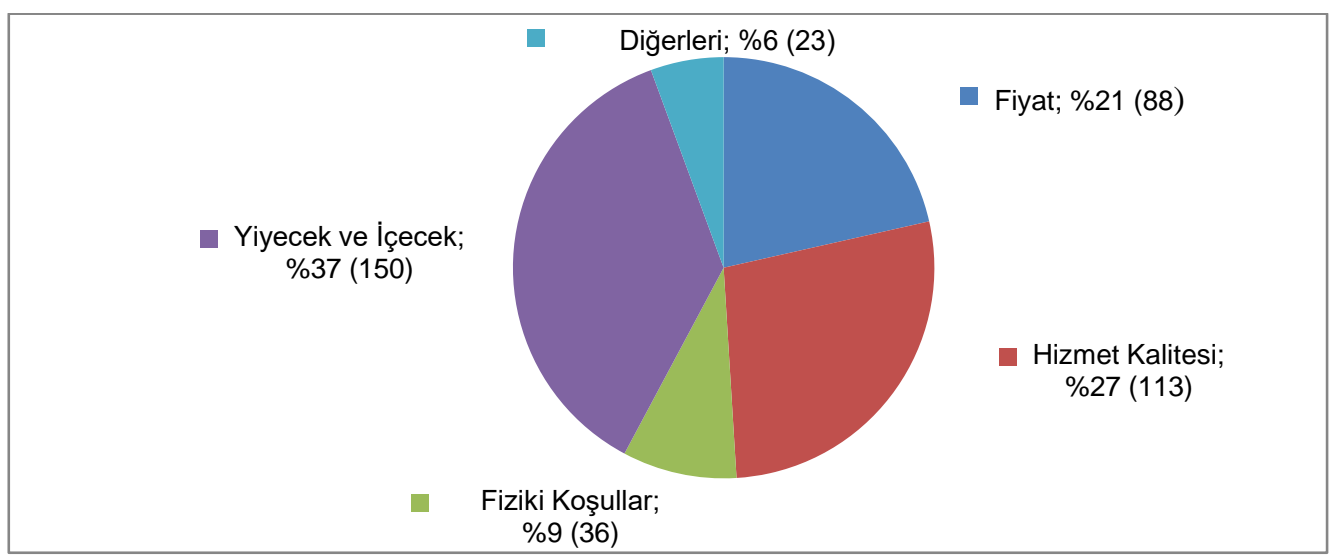

Yiyecek ve içecek konusunda toplam 150 şikâyet bulunmaktadır. En fazla şikâyetler; porsiyon miktarı (\%20), kahvaltıdaki yiyeceğin orijinalliği (\%18), yiyeceğin kalitesi (\%18) ve kahvaltılıkların çeşitliliği (\%18) konusunda yapılmıştır. Bu şikâyetleri lezzet (\%12), uygun pişirme/uygun sıcaklık (\%5), tazelik (\%4), gıda hijyeni (\%3), artan yiyeceklerin tekrar servis edilmesi (\%2) konuları takip etmektedir (Şekil 2). Birçok müşteri kahvaltılıkların Van'a has doğal ve yerel yiyecekler olmadığını ifade ederek, piyasadaki herhangi bir marketten satın alınan sıradan ürünler olmasından yakınmaktadır. Benzer bir şekilde birçok müşteri porsiyonların miktarından ve kahvaltıdaki malzeme çeşitliliğinin kısıtlanmasından şikâyetçi olmuştur. Yorumlarından anlaşılan müşterilerin Van kahvaltı salonlarına kalite, doğallık, yerellik ve çeşitlilik beklentisi içinde gittikleri, Van kahvaltısı denilince gözleri ve karınları doyuran mükellef bir menü bekledikleri anlaşılmaktadır. Konu ile ilgili yapılan bir yorum:

"Kaliteli ve bol çeşit bir kahvaltı için gittik. Adı Van kahvaltı salonu ama Van'la alakası bile yok, adamlar peynir tabağına sayılı peynir koymuşlar. Masaya koydukları her şey sayılı gibiydi çok azdı. Fazla çeşit yoktu. Gözümüz bile doymadı...".

Şekil 2: Yiyecek ve İçecekle İlgili Şikâyetlerin Alt Temalarına Göre Frekans ve Yüzdelik Oranları

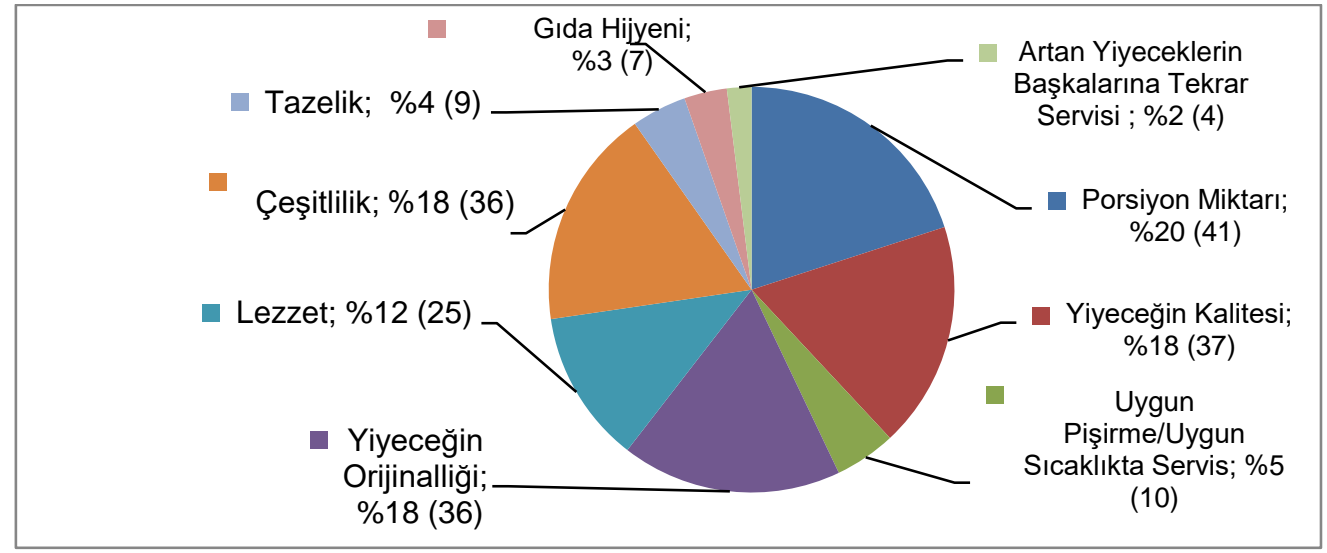

Yine müşteri yorumlarından anlaşıldığı kadarıyla, özellikle Van dışındaki kahvaltı salonlarının doğalık, yerellik, orijinallik, tazelik konusunda daha özenli ve dikkatli olması gerektiği anlaşılmaktadır. Konuyla ilgili müşteri yorumlarından bazı alıntılar: 
"Gelen kahvaltılar doğal ürün değildi, market ürünleri idi. Sadece otlu peynir ve bal doğal, diğer ürünler çok sıradan hiçbir özelliği yoktu...”.

“...Peynirler en ucuz-kalitesiz market ürünü, 3 çeşit kavrulmuş un, yenemeyecek tatta ve lezzette kaymak, bal ve yumurta yiyecekleri masada bırakıp kalkıyorsunuz...".

“...Yöresel ürün tüketme beklentisiyle gidilmemeli. Yöresel ürün anlamında lezzetli tek ürün Van otlu peyniriydi. Diğerleri lezzetsiz ve bayat geldi, ikram edilen kahvaltılıklar lezzetli değildi. Van bölgesine ait özel bir lezzet var mı, yok mu? Onu bile anlayamayacağınız kadar vasat...".

Hizmet kalitesi konusunda toplam 113 şikâyet bulunmaktadır. En fazla şikâyetler; yiyeceğin sunumu (\%26), personelin ilgisizliği (\%27), işletme ve personelin hizmet anlayışı (\%21) konusunda yapılmıştır. Bu şikâyetlerden sonra personelin kabalığı (\%15) ve vasıfsızlığı (\%11) gelmektedir (Şekil 3). Birçok müşteri yiyecek ve içeceklerin uygun olmayan tabak ve bardaklarla servis edildiğini, serviste bir düzenin olmadığını ve düzgün sipariş alınmadığından yakınmaktadır. Müşteriler, personelin ilgisizlik ve bıkkınlık hallerinden yakınarak işletme ve personelin hizmet anlayışından şikâyetçi olmuşlardır. Yapılan yorumlar, müşterilerin Van kahvaltısının hizmet kalitesiyle ilgili beklentilerinin yüksek olduğunu ortaya koymaktadır. Ancak hizmet kalitesinin bazı müşterilerin beklentilerinin altında kaldığı görülmektedir. Konuyla ilgili müşteri yorumlarından bazıları:

"Sana kimse bir şey sormuyor. Her şey kafalarına göre ne içersin, çayı nasıl içersin ya da yumurtan nasıl olsun diyen yok. Insanların istekleri bu kadar önemsiz olmamalı...".

"Çok reklamı olduğundan kalabalık oluyor, ye kalk diye başında bekliyorlar. 10 dakikada ye git istiyorlar. Insanlar kahvaltıda arkadaşları iyi güzel zaman geçirmek için dışarı çıkıyor, başınızda haydi ye git diyen garsonlar olması çok sinir bozucu, daha kalabalık bir grup gelince yemek ortasında haydi yan masaya geçin diyebiliyorlar..."

Şekil 3: Hizmet Kalitesiyle İlgili Şikâyetlerin Alt Temalarına Göre Frekans ve Yüzdelik Oranları

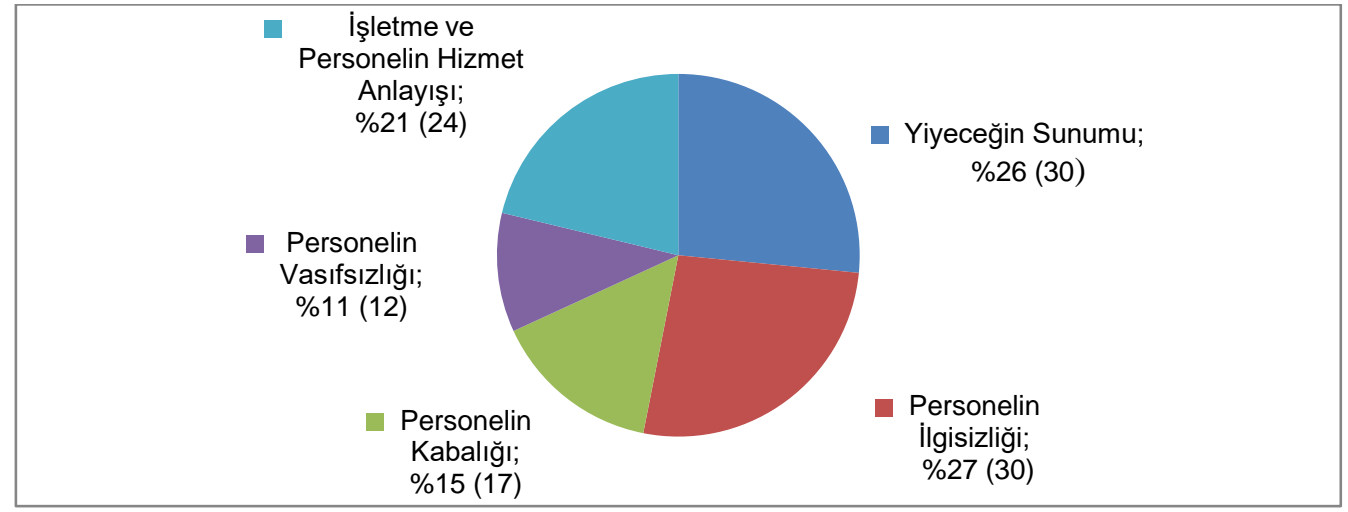

Van kahvaltı salonlarının hizmet kalitesi, özellikle de işgörenlerin ilgisizliği ve vasıfsızlığı daha çok yabancı müşterileri rahatsız etmiştir. Bu müşteriler, konu ile ilgili şikâyetlerini daha belirgin kelimelerle ifade etmişlerdir.

"... When we went there for a sunday brunch and complained about one table who was smoking like hell, although we were inside, we felt terrible and told the waiter, 
but the staff just ignored us. That made us resolve the problem with the people smoking. We had a very bad argument with those people and the staff did nothing. We will never go back there..."

"I like having breakfast on weekends. But do not waste your precious time here. They fail at everything. They do not have proper seating arrangement. Waiters are a loof and nobody seems to be in charge. You can never be sure if they have taken your order or not...".

Fiyat konusunda toplam 88 şikâyet bulunmaktadır. Buradaki başlıca şikâyetler; kahvaltı fiyatının pahalı olması (\%71), ek ücret alınması (\%15) ve kişi başı ücret uygulaması (\%14) olmuştur (Şekil 4). Fiyatla ilgili şikâyetleri olan müşteriler fiyatın beklentilerinin üstünde olduğunu, fiyat kalite ilişkisinin abartıldığını, ek ücret alınmasından rahatsız olduklarını ve kişi başı fiyat uygulamasının doğru olmadığını ifade etmektedirler. Özellikle ailece gidenlerin ek ücret ve kişi başı fiyat uygulamasından daha çok rahatsız oldukları anlaşılmaktadır. Bu aileler dört kişiyiz ancak bize üç kişilik kahvaltı menüsü yeterli neden 4 kişilik menü almak zorundayız şeklinde şikâyetleri olmuştur. Konuyla ilgili müşteri yorumlarından bazıları:

"Fiyatlar gereksiz pahalı. Getirilen kahvaltıyı 1 kişi yerse 30 TL, 2 kişi yerse 60 $T L$, 3 kişi yerse 90 TL diye devam edecek olan sarmal...". Fiyat konusundaki rahatsızlığı ifade eden diğer yorum "Yani meşhur Van kahvaltısı diyorlar ama meşhur olan kahvaltıyı sıradan para kahvaltısı yapıyorlar...".

“...Kahvaltıda iddialı olmayan mekânlarda bile sınırsız çay mevcut iken kahvaltı salonu olarak açık olan bir yerde ekstra çay parası vermek hoş değil... Özellikle kahvaltı öncesinde bunu sormama rağmen ekstra demlik ücreti alındı...".

\section{Şekil 4: Fiyatla İlgili Şikâyetlerin Alt Temalarına Göre Frekans ve Yüzdelik Oranları}

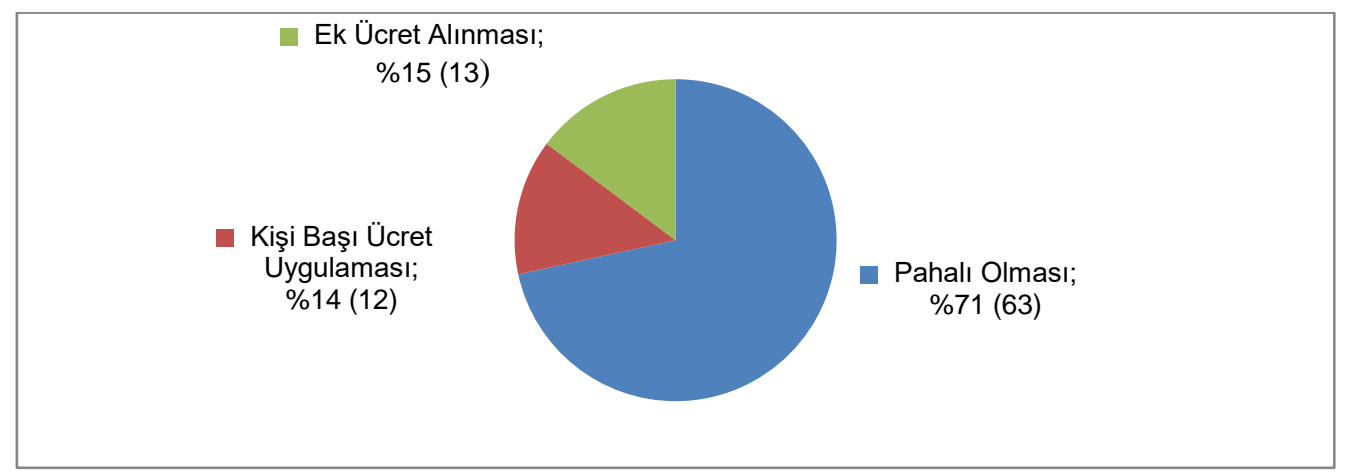

İşletmelerin fiziki koşulları konusunda toplam 36 şikâyet bulunmaktadır. En çok şikâyet mekânın ve masaların temizliği (\%41) konusunda olmuştur. Bunu ambiyans (\%35), havalandırma (\%15) ve dekorasyon (\%9) konusundaki şikâyetler takip etmektedir (Şekil 5). Yorumlardan anlaşılan Van kahvaltı salonlarından bazılarının fiziki koşullarının müşteri beklentilerinin altında kaldığı yönündedir. Bu işletmelerin eksikliklerini tamamlayarak Van kahvaltı salonlarına layık bir şekilde hizmet etmesi beklenmektedir. Konuyla ilgili müşteri yorumlarından bazıları: 
“...Rezerve yaptırıp adres tarifi alarak gittik. Bizi kirli masalara oturtmak istediler masa kirli deyince başkasına ayırdıkları masaya oturttular... Resmen insanlarla dalga geçiliyor... Paranızla rezil oluyorsunuz!".

"The place is WAY too hot (we had to sit inside cuz all the tables outside were taken). We asked them to turn a fan on or something, the waitress said I dont know and left. Who wants to spend an hour having breakfast in 40 degrees? I honestly dont know...".

Şekil 5: Fiziksel Ortamla İlgili Şikâyetlerin Alt Temalarına Göre Frekans ve Yüzdelik Oranları

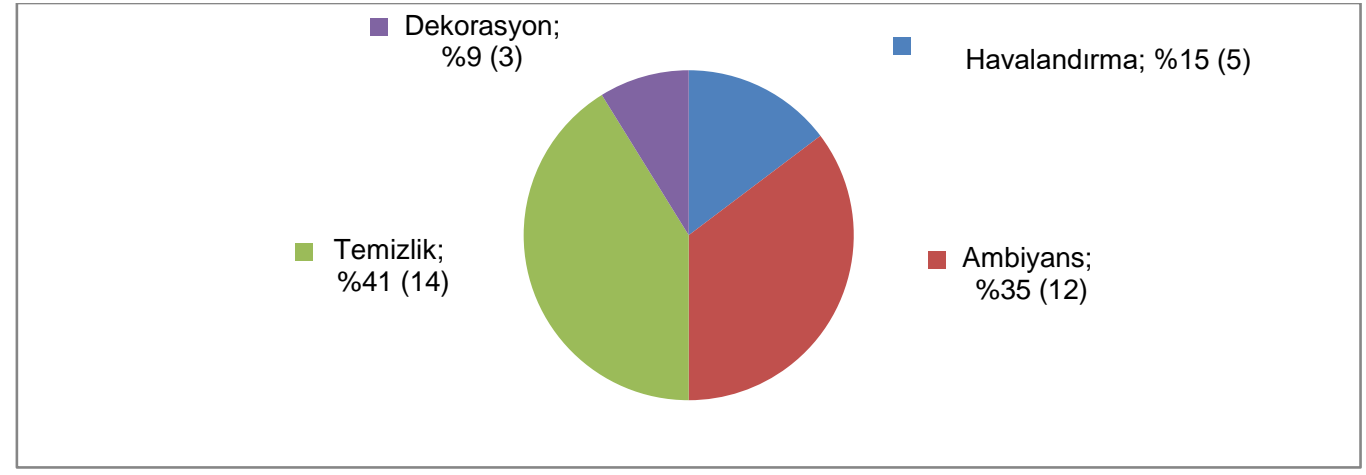

Diğer konularda toplam 23 şikâyet bulunmaktadır. En çok şikâyet edilen konu mekânın kalabalık (\%61) olmasıdır. Mekânın kalabalık olmasına bağı olarak müşterinin sıra beklemek (\%22) zorunda kalması diğer bir şikâyet konusu olmuştur. Bu temel iki konu dışında farklı konularda 4 şikâyet (\%17) daha yapılmıştır (Şekil 6). Müşteri yorumları Van kahvaltı salonlarına yoğun bir talebin mevcut olduğunu, masadaki müşterilerin sohbet eşliğinde uzun süre kahvaltılarına devam ettiklerini, bu durumun mekânın kalabalık ve gürültülü olmasına neden olduğunu ve bazı sorunları beraberinde getirdiğini ortaya koymaktadır. Konuyla ilgili müşteri yorumlarından bazıları:

“...lçerisi tıkış tıkış ve gürültülü. Bir masa bulup oturduk 10 dakika sonra 1 tabak geldi gele gele. Aradan 20 dakika geçti kahvaltılıklar. 10 dakika çatalları bekleyip sonra biz istedik. 10 dakika ekmeğin gelmesini bekledik gelmeyince biz istedik... Bu kalabalığa, bu eziyete değmez...”.

Şekil 6: Diğer Şikâyetlerin Alt Temalarına Göre Frekans ve Yüzdelik Oranları

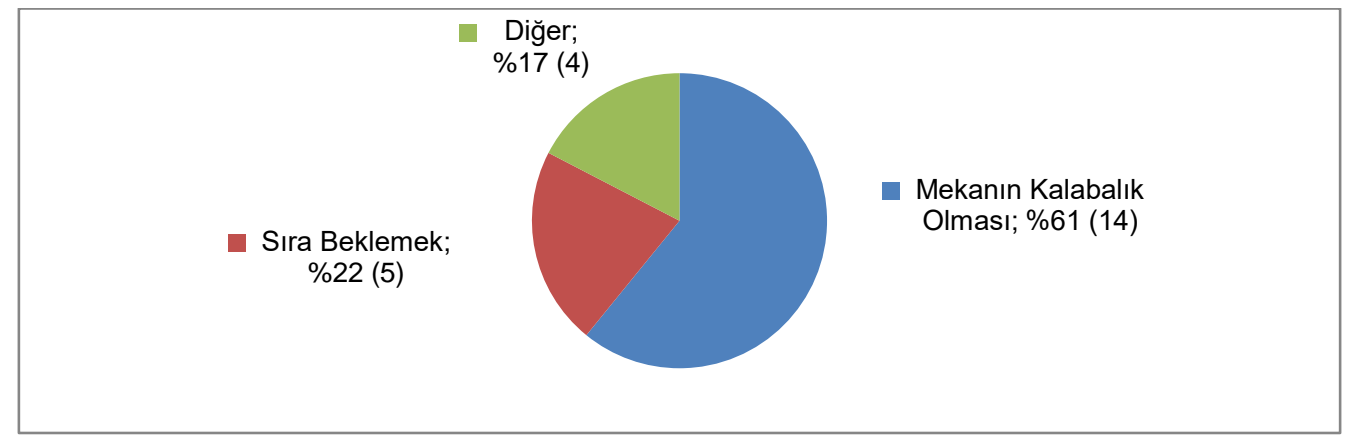




\section{Sonuç ve Öneriler}

Günümüzde yiyecek içecek ve diğer turizm işletmelerinin sunduğu hizmetlerden faydalanan müşteriler, bu işletmelerde yaşadıkları deneyimlerini sosyal medya platformlarında veya değişik internet sitelerinde paylaşmaktadırlar. Diğer taraftan belli bir hizmeti veya ürünü satın almak isteyen potansiyel müşteriler de bilgi edinmek için diğer müşterilerin deneyimlerini bu platformlardan takip etmektedirler. Böylece müşterilerin birbirini etkilemesi ve yönlendirmesi mümkün olabilmektedir. Memnuniyet içeren müşteri değerlendirme ve yorumları işletmelere avantaj sağlarken, şikâyet içerikli değerlendirme ve yorumlar işletmeler için bir tehdit oluşturabilmektedir. Bu bakımdan işletmelerin müşteri şikâyetlerini önemsemeleri, onları dikkate almaları, uygun çözümler üretmeleri ve şikâyete neden olan hataları tekrarlamamaları gerekir.

Bu araştırmada elde edilen bulgulara dayanarak müşterilerin genel anlamda Van kahvaltı salonlarından memnun oldukları söylenebilir. Ancak araştırmanın temel konusu Van kahvaltı salonlarından memnun olmayan müşterilerin niçin memnun olamadıkları, diğer bir ifade ile Van kahvaltı salonlarında müşteri şikâyetine konu olan unsurların tespit edilmesidir. Araştırma müşteri şikâyetlerinin 5 ana tema ve 24 alt temadan kaynaklandığını ortaya koymaktadır. En fazla şikâyet yiyecek ve içecek, hizmet kalitesi ve fiyat konusunda yapılmıştır. Bunları fiziki koşullar ve diğer konularda yapılan şikâyetler takip etmektedir. Araştırma alanı her ne kadar şimdiye kadar yapılan araştırmalardan farklı olsa da tespit edilen şikayetlerin ana temalarının büyük bir kısmı diğer araştırma sonuçlarıyla benzerlik göstermektedir (Su ve Bowen, 2000; Defranco ve diğ., 2005; Liu ve Jang, 2009; Chan ve diğ., 2016; Erdem ve Yay, 2017; Taştan ve Kızılcık, 2017; Şahin ve diğ., 2018; İbiş ve diğ., 2019; Yaşar, 2019).

Araştırmada şikâyet konusu olarak tespit edilen alt temalarından bazıları diğer araştırmalardan farklılık göstermektedir. Bu farklılıklar; yiyecek içecek ana teması altında porsiyon miktarının az olması ile diğer masalarda artan yiyeceklerin başka masalara servis edilmesi veya peynir gibi artan yiyeceklerin gözleme gibi yiyeceklerde kullanılması alt temaları olmuştur. Fiyat ana teması altında farklılık gösteren alt tema, tekrar istenen yiyecek ve içeceklerden ek ücret alınması ve porsiyon miktarı ölçüsünün dikkate alınmayıp kişi başı ücret alınması olmuştur. Diğerleri ana teması altında mekânın çok kalabalık olması ve mekânın kalabalık olmasına bağlı olarak dışarıda veya servis masasında sıra beklemek bu araştırmada tespit edilen diğer bir farklılıktır.

Araştırma sonucu elde edilen bulgulardan yola çıkarak Van kahvaltısı salonu işletmecilerine bazı önerilerde bulunulabilir. Van kahvaltı salonlarına gelen müşterilerin yorumlarından anlaşılan, müşterilerin büyük bir kısmının Van kahvaltı solanlarına yönelik yorumları önceden okudukları, bu kahvaltı salonlarına kalite, doğallık, yerellik, orijinallik, tazelik ve çeşitlilik beklentisi içinde gittikleri, Van kahvaltısı denilince gözleri ve karınları doyuran mükellef bir menü bekledikleri anlaşılmaktadır. Bu noktada işletmelerin öncelikli olarak dikkat etmesi gereken konu porsiyon miktarını azaltmadan Van yöresine ait yerel ve doğal yiyecekleri kullanmaya özen göstermeleri, market ürünlerinden ve hazır gıdalardan uzak durmaları, orijinallik, kalite, çeşitlilik ve lezzetten ödün vermemeleridir. Müşterilerin şikâyetçi oldukları ikinci önemli tema hizmet kalitesi olmuştur. Burada da işverene ve işgörene büyük görev ve sorumluluklar düşmektedir. Kahvaltı salonları ne kadar yoğun olursa olsun müşterilere nezaket kuralları çerçevesinde hizmet edilmelidir. İşletmelerin nitelikli personel istihdam etmeleri, mevcut işgörene de servis, müşterilerle iletişim, nezaket ve görgü kuralları gibi konularda eğitim vermeleri olumlu sonuçlar verecektir. Müşterilerin şikâyetçi oldukları üçüncü önemli tema işletmelerin fiyat politikası olmuştur. İşletmelerin fiyat politikalarını gözden geçirmeleri gerekir. Kahvaltı menü kartında, standart kahvaltı menüsünün 
neleri kapsadığının açık ve anlaşılır bir şekilde yazılması, hangi yiyecek ve içeceklerden ek ücret alındığı ve bunların fiyatlarının yazılması bu konudaki şikâyetleri önemli oranda ortadan kaldırabilir.

Müşteri yorumlarından Van kahvaltı salonlarının ambiyans, havalandırma, temizlik ve yöresel dekorasyona da önem vermeleri gerektiği anlaşılmaktadır. Diğer bir öneri, mekânların yoğunluğunu azaltmak dolayısıyla müşterinin kapıda veya kirli masalarda beklemesini önlemek için kalabalık gruplar için rezervasyon uygulaması teşvik edilebilir ve kahvaltı salonlarının girişinde müşterilerin oturarak bekleyebileceği bir alan oluşturulabilir. Kahvaltı salonu işletmecilerine yapılabilecek son öneri, müşteri velinimettir ve her müşteri değerlidir. Bu anlayıştan hareketle şikâyet içerikli müşteri yorumlarından rahatsız olunmamalı, şikâyetler dikkate almalı, analiz edilmeli, sorunlar tespit edilerek çözüm odaklı politikalar sergilenmelidir.

Kamu kurum ve kuruluşlarına da bazı öneriler getirilebilir. Yiyecek içecek işletmelerine yönelik gıda güvenliği, hijyen, temizlik vb. konularda denetleme ve yaptırım yetkisi olan Turizm Bakanlığı, Tarım Bakanlığı, Sağlık Bakanlığı, belediye ve diğer kamu kurum ve kuruluşlarının da kendi yetki alanına giren konularda denetimlerini düzenli olarak yapmaları, kurallara uymayan işletmelere yaptırım uygulamaları, müşteri haklarını korumaları ve müşteri şikâyetlerinin takipçisi olmaları gerekir.

Kahvaltı salonu işletmelerine yönelik müşteri şikâyetleri yeterince çalışılan bir konu olmadığından bu konuda yeni araştırmalar yapılabilir. Ayrıca turizm işletmelerinin müşteri şikâyetlerini ne denli dikkate aldıkları, geri bildirimleri, şikâyetlere nasıl çözümler ürettikleri ve bu çözüm yöntemlerinden müşterilerin ne oranda memnun kaldığına yönelik araştırmalar da literatüre katkı sağlayacaktır.

\section{Kaynakça}

Akoğlan Kozak, M. ve Güçlü, H. (2006), Turizmde Etik, Kavramlar Illkeler Standartlar, 1. Baskı, Ankara: Detay Yayıncılık.

Alabay, M. N. (2012), 'Müşteri Şikâyetlerinin Yönetimi' Uluslararası Yönetim Iiktisat ve Işletme Dergisi, 8(16), ss. 137-158.

Aşkun, O. B. (2008), 'Şikâyet İletilerinin Örgütsel Öğrenme Üzerine Etkisi' Marmara Üniversitesi i.i.B.F. Dergisi, 24(1), ss. 221-243.

Aylan, S., Arpacı, Ö. ve Celiloğlu, F. K. (2015), 'Bir İnternet Şikâyet Formundaki Termal Otellere Yönelik Şikâyetlerin İncelenmesi' Çankırı Karatekin Üniversitesi Sosyal Bilimler Enstitüsü Dergisi, 7(1), ss. 49-68.

Barlow, J. ve Moller, C. (2008), A Complaint is A Gift: Recovering Customer Loyalty When Things Go Wrong, San Francisco, California: Berrett-Koehler Publishers.

Bell, S. J., Mengüç, B. ve Stefani, S. (2004), 'When Customers Disappoint: A Model of Relational Internal Marketing and Customer Complaints' Journal of the Academy of Marketing Science, 32(2), ss. 112-126.

Chan, G. S. H., Hsiao, A. C-H. ve Lee, A. L. Y. (2016), 'Exploration of Customer Complaint Behavior toward Asian Full-Service Restaurants' International Journal of Marketing Studies, 8(29), ss. 46-58.

Çuhadar, M. ve Güney, Ö. İ. (2018), 'Kırsal Turizm Bölgelerindeki Restoranlara Yönelik Çevrimiçi Müşteri Değerlendirmelerinin Analizi: Eğirdir Örneği' Uluslararası İktisadi ve Idari Bilimler Dergisi DEAS, 4(1), ss. 160-165.

Dalgıç, A., Güler, O. ve Birdir, K. (2016), 'Tripdvisor.com'da Yer Alan Restoran Şikâyetlerinin Analizi: Mersin ve Hatay'da Yöresel Yiyecek Sunan Restoranlara 
Yönelik Bir Araştırma' Journal of Tourism and Gastronomy Studies, 7(Special Issuel), ss. 153-173.

Defranco, A., Wortman, J., Lam, T. ve Countryman C. (2005), 'A Cross-Cultural Comparison of Customer Complaint Behavior in Restaurants in Hotels' Asia Pasific Journal of Tourism Research, 10(2), ss. 173-190.

Erdem, Ö. ve Yay, Ö. (2017), 'Tripadvisor'daki Müşteri Şikâyetlerinin Değerlendirilmesi: Antalya Örneği' Journal of Tourism and Gastronomy Studies, 5(4), ss. 227-249.

Genç, K. ve Batman, O. (2018), 'Tarihi Konak İşletmelerine Yönelik E-Şikâyetlerin Değerlendirilmesi: İpekyolu Ayaş-Sapanca Koridoru Üzerine Bir Araştırma' Uluslararası Yönetim Iktisat ve İşletme Dergisi, 14(1), ss. 283-296.

Giritlioğlu, İ., İpar, M. S. ve Sevinç, R. (2016), 'Osmanlı ve Türk Mutfağına Yönelik Faaliyet Gösteren Yiyecek İçecek İşletmelerinde Müşteri Şikayetlerinin Incelenmesi: Antalya Bölgesi Kapsamında Bir Araştırma' 3rd International Congress on Social Sciences, China to Adriatic, October 27-30, Antalya, ss. 204-217.

Gursoy, D., McCleary, K. W ve Lepsito, L. R. (2003), 'Segmenting Dissatisfied Restaurant Customers Based on Their Complaining Response Styles' Journal of Foodservice Business Research, 6(1), ss. 25-44.

İbiş, S., Kızıldemir, Ö. ve Çöp, S. (2019), 'İstanbul'daki Çin Restoranlarına Yönelik Yapılan Yorumların ve E-Şikayetlerin Değerlendirilmesi' Journal of Tourism and Gastronomy Studies, 7(1), ss. 505-521.

ISO-International Standard Organizations (2018), 'Complaint' www.iso.org/standard/71580.html (24.04.2020).

KalDer-Türkiye Kalite Derneği (2020), 'Müşteri Memnuniyeti' www.kalder.org/musteri_memnuniyeti_ve_sikayetlerin_etkili_yonetimi_1gun (25.04.2020).

Kılıçhan, R. ve Köşker, H. (2015), 'Destinasyon Markalaşmasında Gastronominin Önemi: Van Kahvaltısı Örneği' Journal of Tourism and Gastronomy Studies, 3(3), ss. 102-115.

Kim, J-H. ve Chen, J. S. (2010), 'The Effects of Situational and Personal Characteristics on Consumer Complaint Behavior in Restaurant Services' Journal of Travel \& Tourism Marketing, 27(1), ss. 96-112.

Kozak, M. (2007), 'Turizm Sektöründe Tüketici Şikâyetlerini Belirleme Eğilimleri' Celal Bayar Üniversitesi I.I.B.F. Dergisi, 4(1), ss. 137-151.

Liu, Y. ve Jang, S. S. (2009), 'Perceptions of Chinese Restaurants in the US: What Affects Customer Satisfaction and Behavioral Intentions?' International Journal of Hospitality Management, 28(3), ss. 338-348.

Nakiboğlu, M. (2017), 'Van'da Kahvaltı Kültürü ve Kahvaltı Salonları' IWACT'17 International West Asia Congress of Tourism Research, 28 September- 01 October, Van, ss. 332-339.

Phau, I. ve Sari, R. P. (2004), 'Engaging in Complaint Behaviour An Indonesian Perspective' Marketing Intelligence \& Planning, 22(14), ss. 407-426.

Ro, H. (2013), 'Customer Complaining Behaviors After Restaurant Service Failure: Redress Seeking Complaint, Friendly Complaint, Loyalty and Neglect' International Journal of Tourism Sciences, 13(1), ss. 27-46.

Su, W. Y. ve Bowen, J. T. (2000), 'Restaurant Customer Complaint Behavior' Journal of Restaurant \& Foodservice Marketing, 4(2), ss. 35-65.

Şahin, S., Girgin, G. K., Kazoğlu, İ. H. ve Coşkun, G. N. (2018), 'Gastronomi Turistlerinin E-Şikâyet Davranışları Üzerine Bir Araştırma: Alaçatı Örneği' Journal of Tourism and Gastronomy Studies, 6(1), ss. 68-82.

Taştan, H. ve Kızılcık, O. (2017), 'Kahramanmaraş'ta Bulunan Yiyecek İçecek İşletmelerine Yönelik Tripadvisor.com'da Paylaşılan Şikâyetlerin Sınıflandırılması' Ç.Ü. Sosyal Bilimler Enstitüsü Dergisi, 26(1), ss. 270-284. 
TripAdvisor, (2020), '2019 TripAdvisor Review Transparency Report' www.tripadvisor.com.tr/TripAdvisorlnsights/wp-content/uploads/2019/09/2147 PR_Content_Transparency_Report_6SEP19_US.pdf (17.04. 2020).

Unur, K., Şeker, F. ve Erdem, A. (2017), 'Adana İlinde Bulunan Restoranlara Yönelik İnternet Üzerinden Yapılan Tüketici Şikâyetlerinin İncelenmesi: Tripadvisor.com Örneği' Futur Tourism, September 28-30, Mersin, ss. 1366-1376.

Velazquez, B. M., Contri, G. B., Saura, I. G. ve Blasco, M. F. (2006), 'Antecedents to Complaint Behaviour in the Context of Restaurant Goers' Int. Rev. of Retail, Distribution and Consumer Research, 16(5), ss. 493-517.

Yaacob, Z. (2010), 'Performance of Local Authorities: Analysis on Two Different Levels of Quality Adoption' African Journal of Business Management, 4(14), ss. 31693177.

Yaşar, Z. (2019), ‘Kastamonu'da Yöresel Yiyecek İçecek Hizmeti Sunan Restoranlara 'Iliş̧kin Tüketici Şikâyetlerinin Değerlendirilmesi: Tripadvisor Örneği' Safran Kültür ve Turizm Araştırmaları Dergisi, 2(2), ss. 241-250.

Yıldırım, A., ve Şimşek, H. (2011), Sosyal Bilimlerde Nitel Araştırma Yöntemleri, 8. Tıpkı Basım, Ankara: Seçkin Yayıncılık.

Yurtseven, H. R., Erkul, H. ve Morkoç, D. K. (2013), Örneklerle Sosyal Bilimlerde Araştırma Yöntem ve Teknikleri, Ankara: Detay Yayıncılık. 